\title{
Absorption of Pseudomonas morsprunorum through Cherry Leaf Scars
}

\author{
By R. C. HIGNETT \\ East Malling Research Station, Maidstone, Kent \\ (Received 20 July 1973; revised 29 August 1973)
}

SUMMARY

The absorption of cells of a cherry strain of Pseudomonas morsprunorum through leaf scars into the leaf traces of cherry cultivar Napoleon was not affected when $10 \times$ more cells of a plum strain were present, although this could inhibit the development of the disease. Ninety per cent of ${ }^{14} \mathrm{C}$-labelled cherry inoculum was deposited within $2 \mathrm{~mm}$ of the entry point, with small amounts extending $25 \mathrm{~mm}$ into the host in the presence or absence of the plum strain. Bacteria were observed in regular arrays inside the vessels of the leaf traces, and there was evidence that bacteria migrated from these to other tissues within 5 days of inoculation. No visible damage or changes in the phenolic content of the host were observed during this period.

\section{INTRODUCTION}

Bacterial canker of cherry (Prunus avium) is caused by cherry strains of Pseudomonas morsprunorum entering the vessels exposed by leaf abscission. The bacteria multiply within the host and eventually kill the invaded tissues. The disease can be inhibited by the presence in the inoculum of strains of the bacterium isolated from plum (Crosse \& Garrett, 1970). This paper describes the deposition and migration of a ${ }^{14} \mathrm{C}$-labelled cherry strain of $P$. morsprunorum in the host during the first few days after inoculation, by determination of the distribution of radioactivity and by histological methods.

\section{METHODS}

Bacterial cultures were generally grown for $24 \mathrm{~h}$ at $25{ }^{\circ} \mathrm{C}$ in shaken flasks containing I \% nutrient broth and $2 \%$ glycerol. The cherry isolate $\mathrm{C} 46$ was grown in a medium containing $0.1 \%$ peptone and $0.05 \%$ glycerol supplemented with $\left[{ }^{14} \mathrm{C}\right]$ glycerol-(U) (I00 $\left.\mathrm{mCi} / \mathrm{ml}\right)$. The bacteria were harvested and washed three times in distilled water with centrifugation at $\mathbf{I} 7000 \mathrm{~g}$ for $5 \mathrm{~min}$ to remove adhering radioactive substances, then resuspended in water at a concentration of $5 \times 10^{7} \mathrm{cells} / \mathrm{ml}$. The plum strain DIO was grown in non-radioactive culture, harvested and washed in the same way and used at $3 \times 10^{8}$ cells $/ \mathrm{ml}$. Inoculations were done immediately and samples taken for viability tests.

One-year-old branches (about I m long) of cherry cultivar Napoleon were cut from $12-$ year-old trees and stood in distilled water in the laboratory, in daylight. Molten petroleum jelly was painted round the proximal ends of alternate petioles and allowed to set. The petioles were then removed as required, the two outer leaf traces plugged with petroleum jelly, and $0.005 \mathrm{ml}$ of inoculum pipetted immediately onto the centre trace. Tests with $0.5 \%$ aqueous safranin had previously shown that penetration by this technique gave results comparable to those obtained with intact plants in the field. Inoculations were randomized among replicate branches. Replicate stem samples for autoradiography and histological 
work were taken at random and leaf scars were cut out and trimmed before being fixed under vacuum in $5 \%$ formaldehyde. They were then dehydrated in alcohol and embedded in paraffin wax. Cut sections were dewaxed in xylene, stained for $30 \mathrm{~min}$ in $0.1 \%$ carbolthionine dissolved in $5 \%$ phenol, counterstained in saturated ethanolic orange $\mathrm{G}(2 \mathrm{~min})$ and rinsed in alcohol.

Quantitative measurements of radioactivity were done on tissues from Io replicates, which were cut into $2 \mathrm{~mm}$ cubes and ground with pestle and mortar to a smooth paste in the minimum of water for $3 \mathrm{~min}$. No intact segments of leaf trace vessels were visible microscopically in the product. After dilution of the paste with water, the free-bacterium fraction was rapidly isolated by centrifugation at $1400 \mathrm{~g}$ for $5 \mathrm{~min}$, which sedimented the plant debris. The debris was washed once with water in the same way and the pooled supernatants used for radioactivity measurements of the free bacteria. The debris was also washed in some experiments by prolonged $(2 \mathrm{~h})$ suspension in water, $2 \mathrm{M}-\mathrm{NaCl}, 0 \cdot \mathrm{I}$ M-phosphate buffer $(\mathrm{pH} 7 \cdot 0)$, or suspensions of the cherry or plum isolate at $10^{8}$ cells $/ \mathrm{ml}$. Viability tests were done on bacteria isolated from branches which had been surface sterilized by swabbing with $\mathrm{I} \%$ formaldehyde in $50 \%(\mathrm{v} / \mathrm{v})$ alcohol, suitable sterile precautions being taken with subsequent operations. Radioactivity was measured with a Geiger-Müller counter, with compensation for self-absorption by thick samples. AR 50 film (Kodak Ltd, London) was used for autoradiography, with films being developed in Kodak Microdol. Samples were separated from the films during exposure, with Melinex 25 (Boyden Data Papers Ltd, London).

Histochemical tests for phenoloxidase activity were done on fresh leaf-scar sections. Leaf scar sections showing the centre trace were taken over the 5-day period subsequent to inoculation with either distilled water or bacterial suspensions, and were treated with $\mathrm{I} \%$ aqueous catechol for $\mathrm{I} 8 \mathrm{~h}$ at $20^{\circ} \mathrm{C}$ to reveal phenoloxidase activity. Other samples were kept in humid air to reveal indigenous enzyme activity. A third set of sections was treated with diazotized $p$-nitro-aniline to show the presence of phenolic materials.

\section{RESULTS}

Leaf scars were examined after inoculation with a radioactive isolate of Pseudomonas morsprunorum. After $24 \mathrm{~h}$, approximately $90 \%$ of the radioactivity was found in the first $2 \mathrm{~mm}$ layer of tissue adjacent to the leaf-scar surface. The surface layers, which contained about $3 \%$ of the total activity, were previously skimmed off. Traces of activity were detected below this region to a depth of at least $25 \mathrm{~mm}$. Fig. I (a) is an autoradiograph of a longitudinal section of a scar inoculated $24 \mathrm{~h}$ previously. The massive retention of inoculum within the first $2 \mathrm{~mm}$ of the entry point is shown, with a clearly defined tail of activity penetrating deep into the leaf trace. Fig. I $(b)$ is a combined photograph and autoradiograph of an inoculated leaf scar. Of the total radioactivity recovered during quantitative experiments, $7.8 \%$ was present in the free-bacterium fraction obtained by grinding the tissue in water. The rest was tightly bound to the tissue debris, and was virtually irremovable by washing with the various solutions described, although traces of activity were removed over a period of hours.

Similar samples taken 5 days after inoculation showed that the radioactivity had become dispersed to the point where a defined trace was no longer visible. Quantitative measurements on 5-day-old samples gave results similar to those obtained with $24 \mathrm{~h}$ samples, showing that the radioactivity was still present, although laterally dispersed, with the same gross longitudinal distribution. 


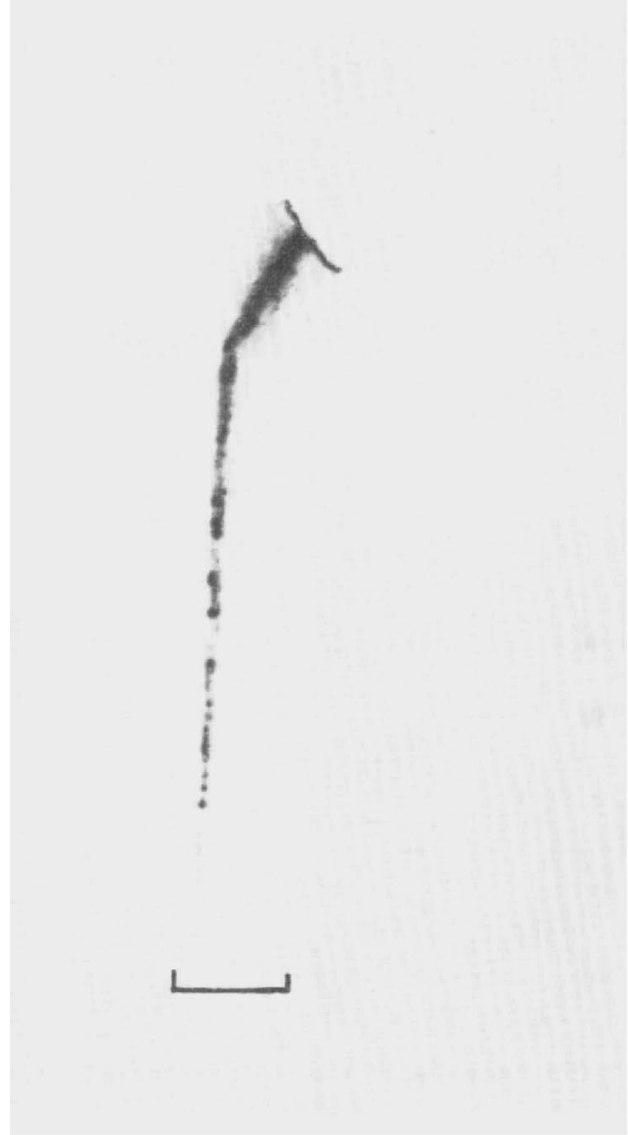

Fig. I $a$.

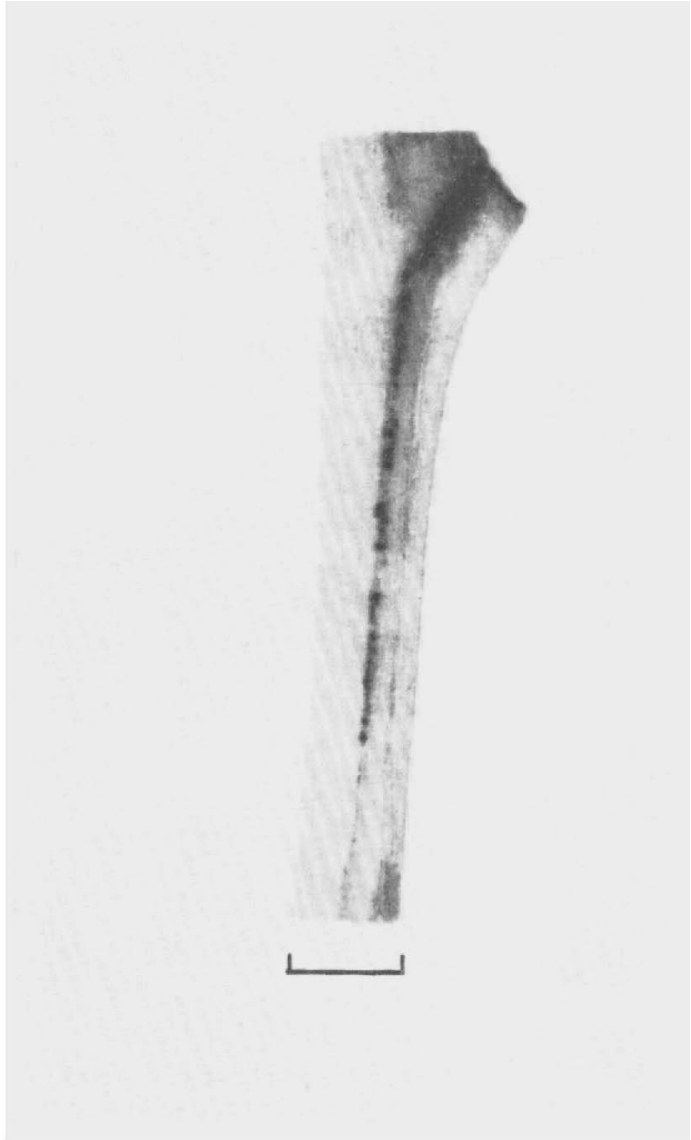

Fig. I $b$.

Fig. I. (a) Autoradiograph of a section of a cherry-leaf scar, taken $24 \mathrm{~h}$ after inoculation with radioactive cherry-strain bacteria. Scale marker $=2 \mathrm{~mm}$. (b) The autoradiograph shown in Fig. I $(a)$, combined with a photograph of its parent section. Scale marker $=2 \mathrm{~mm}$.

The experiments were repeated using a radioactive cherry isolate alone at $5 \times 10^{7}$ cells $/ \mathrm{ml}$ or combined with the plum isolate at $3 \times 10^{8}$ cells $/ \mathrm{ml}$. The autoradiographs of resultant sections were virtually identical to those previously described. In addition, the ratio of the radioactivities of single to mixed inocula was very close to that of the corresponding bacteria recovered from ground-up tissues of both $24 \mathrm{~h}$ and 5-day samples (Table I). Viability measurements on bacterial fractions from $24 \mathrm{~h}$ samples showed that the recovery technique was equally efficien $t$ for both isolates.

Sections cut from $24 \mathrm{~h}$ and 5 -day-old wax-embedded samples were examined for bacteria. Fig. 2 shows bacteria stained with carbolthionine/orange $G$ in a sample taken $24 \mathrm{~h}$ after inoculation with the cherry isolate. Bacteria are spaced equidistantly in rows between the turns of the helical thickening of the leaf trace. Similar results were obtained after inoculation with mixed cherry and plum isolates. Samples taken 5 days after inoculation with either the cherry isolate alone or the mixed cherry and plum isolates, contained bacteria in the outer tissues (Fig. 3). No bacteria were observed outside the leaf traces in $24 \mathrm{~h}$ samples.

The tests for phenoloxidase activity and accumulated phenolic materials showed that 
Table I. Distribution of free and bound radioactivity in leaf scars 24 h after inoculation with radioactive cherry isolate alone, and cherry mixed with non-radioactive plum isolate

Inoculum

Cherry $\left(5 \times 10^{7}\right.$ cells $\left./ \mathrm{ml}\right)$

Cherry $\left(3.1 \times 10^{7}\right.$ cells $\left./ \mathrm{ml}\right)$ plus plum $\left(3 \times 10^{8}\right.$ cells $\left./ \mathrm{ml}\right)$

Ratio of activities, cherry:cherry + plum
Radioactivity (counts/100 s)

$\begin{array}{cccc}\begin{array}{c}\text { Total } \\ \text { applied }\end{array} & \begin{array}{c}\text { Total } \\ \text { recovered }\end{array} & \begin{array}{c}\text { Bacterial } \\ \text { fraction }\end{array} & \begin{array}{c}\text { Plant } \\ \text { debris }\end{array} \\ 26000 & 25600 & 2000(7.8 \%) & 23600 \\ \text { I } 6000 & \text { I5 } 560 & \text { I I90 (7.75\%) } & \text { I4 I } 70 \\ \text { I.62 } & \text { I. } 66 & \text { I.68 } & \text { I.66 }\end{array}$

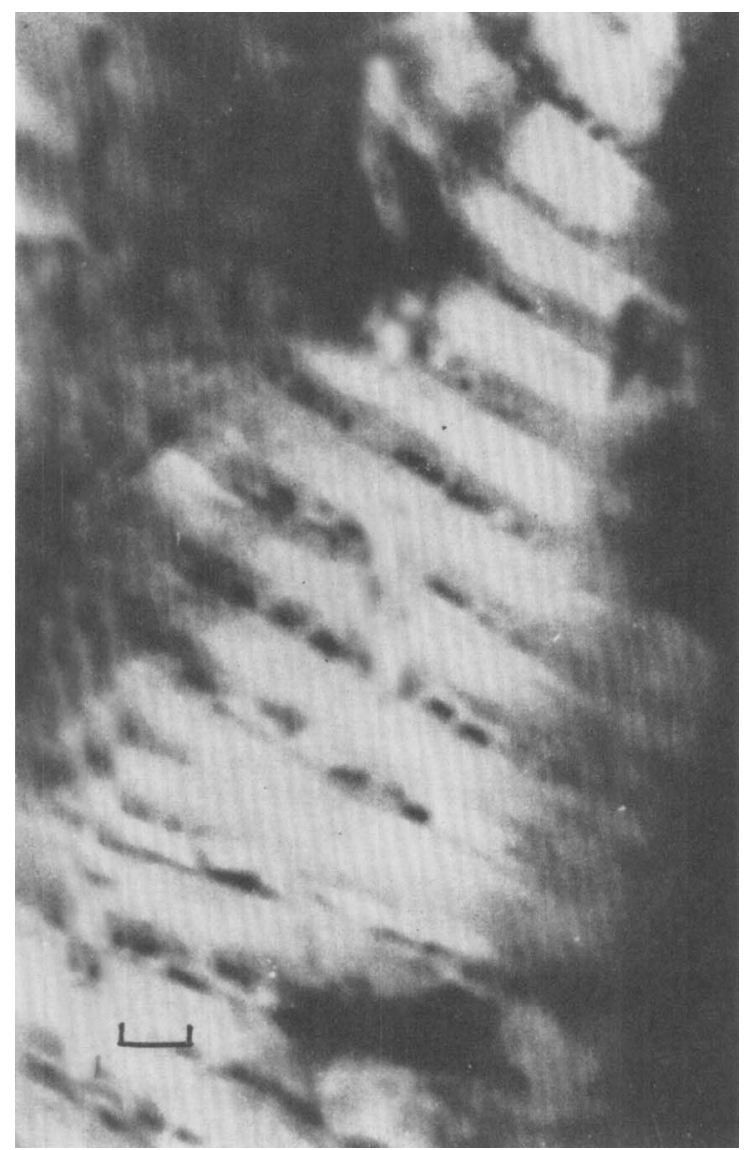

Fig. 2. Stained section of a leaf scar taken $24 \mathrm{~h}$ after inoculation with a cherry isolate, showing rows of bacteria inside the leaf trace. Scale marker $=2000 \mathrm{~nm}$. 


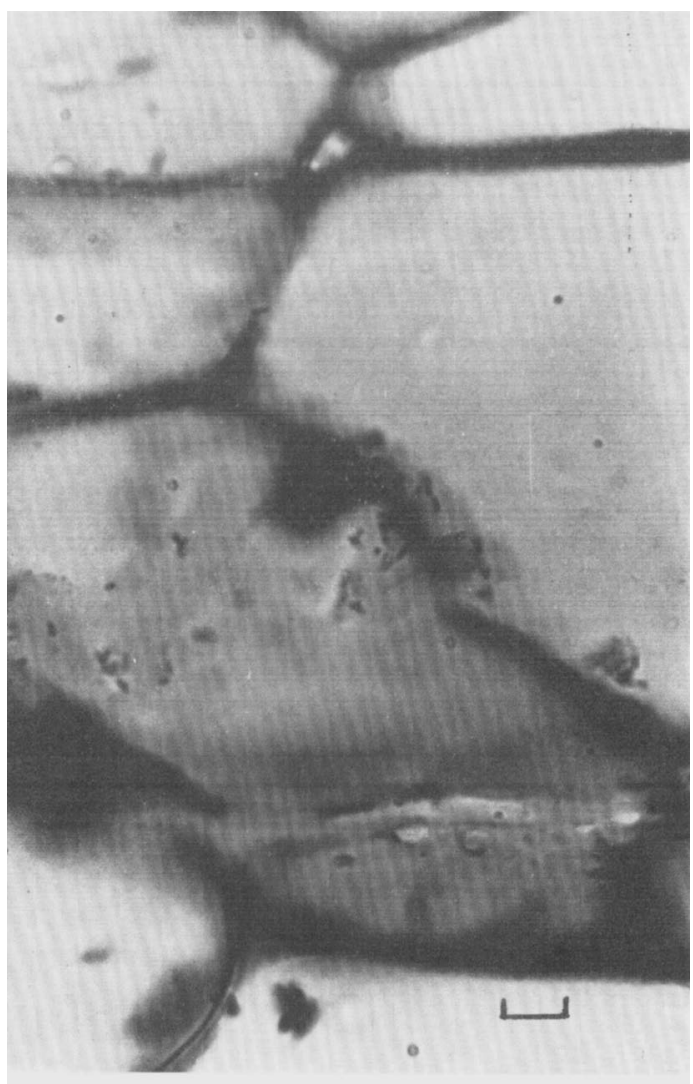

Fig. 3. Stained section of a leaf scar taken 5 days after inoculation with a cherry isolate, showing bacteria in tissues outside the leaf trace. Scale marker $=5000 \mathrm{~nm}$.

no significant changes occurred in leaf scars up to five days after inoculation with bacteria or distilled water.

\section{DISCUSSION}

Although the incidence of bacterial canker caused by a cherry isolate in the cherry cultivar Napoleon can be reduced by the presence of an excess of a plum isolate at high concentration (Crosse \& Garrett, 1970), the results given here show that the pattern of absorption of the cherry isolate is unaffected by the presence of the plum isolate. Thus the retention of $90 \%$ of the cherry inoculum near the entry point, with deep penetration by a small proportion, was unaltered in the presence of a $I 0 \times$ excess of plum isolate under conditions which would have partially inhibited disease development. Similarly, the amount of the cherry isolate recoverable from ground-up tissues up to 5 days after inoculation was unaffected by the presence of the plum isolate.

Five days after inoculation with radioactive cherry strain bacteria, either alone or in combination with a plum strain, the local concentration of radioactivity seen after $24 \mathrm{~h}$ within the leaf scar traces was laterally dispersed, and bacterial cells were observed in the outer tissues. Thus the bacteria apparently escaped within a few days from the leaf trace into the surrounding tissues. This suggests that at some stage, possibly during cell division, 
the bacteria were free to migrate, although the quantitative recovery measurements also suggest that at any one time within the 5-day period the majority of the bacteria remained bound. Lateral dispersion of the radioactivity by diffusible materials (e.g. produced by lysis) might occur. This, however, is unlikely, since at least $80 \%$ of the bacterial carbon must be rendered diffusible, with concomitant loss of viability, to eliminate the leaf-trace radioactivity, and about $90 \%$ of the total radioactivity was inseparable as water-diffusible material from ground-up tissue.

The leaf traces and surrounding tissues showed no visible damage during the 5 days after inoculation with either the cherry isolate or mixed inoculum, nor was there any readily detectable change in the phenolic content, indicating that host responses of this type were weak or non-existent during this period. This accords with the observation that wounded branches support growth of both isolates (Crosse \& Garrett, 1970). Thus the phenomenon of host specificity may be ascribed to events occurring within the leaf scar during the first few hours or days after inoculation, since after this period the bacteria may be expected to multiply in the outer tissues, as both isolates do when inoculated into branch wounds. Host specificity does not seem to arise in this situation.

The regular arrays of bacteria seen in the leaf trace helices may indicate the sites from which bacteria escape into other host tissues. If the rate of escape of cherry bacteria in the first few hours after inoculation were a critical factor in the subsequent development of disease (particularly in view of a weak or slow host reaction), then competitive interactions involving the host, occurring in mixed inocula and affecting the early migration of the cells at this stage, could explain the observed inhibition of disease.

I thank Miss C. M. E. Garrett for the bacterial cultures and viability tests, and A. Quirk and A. L. Roberts for technical assistence.

\section{REFERENCE}

Crosse, J. E. \& Garrett, C. M. E. (1970). Pathogenicity of Pseudomonas morsprunorum in relation to host specificity. Journal of General Microbiology 62, 315-327. 